\title{
Sorbitol Dehydrogenase Gene Expression and Enzyme Activity in Apple: Tissue Specificity during Bud Development and Response to Rootstock Vigor and Growth Manipulation
}

\author{
Ben-Hong Wu and Shao-Hua Li \\ Institute of Botany, Chinese Academy of Sciences, Beijing 100093, China

\begin{abstract}
Marta Nosarzewski ${ }^{1}$ and Douglas D. Archbold
Department of Horticulture, University of Kentucky, N318 Agricultural Science Center North, Lexington, KY 40546
\end{abstract}

\begin{abstract}
Additional INDEX words. Malus $\times$ domestica, SDH, leaves, shoot tips, defoliation, girdling, gibberellin biosynthesis inhibitor, prohexadione-Ca

Abstract. Sorbitol is the primary photosynthate and translocated carbohydrate in apple (Malus $\times$ domestica), and most of it is converted to fructose by sorbitol dehydrogenase (SDH) in sink tissues. We studied the expression of nine $S D H$ genes, SDH activity, and sorbitol content of apple 1) in buds and floral tissues from dormancy to bloom, 2) in leaves and shoot tips of trees on two rootstocks, the moderately vigorous 'Malling Merton 111' (MM.111) and the dwarfing 'Malling 9' (M.9), and 3) in shoot tips in response to application of prohexadione-Ca to suppress shoot growth and defoliation and girdling (D/G) to deprive the shoot tip of sorbitol. In mature, orchard-grown trees, sorbitol was the main soluble carbohydrate in expressed xylem sap from dormancy to bloom at levels over 3- to 6-fold those of glucose and fructose, the other major sugars present. Sorbitol levels there increased from dormancy to its highest concentration at the half inch green stage and declined by bloom, while those of the other sugars increased. SDH activity per milligram of protein increased over 4-fold from dormancy to flowering. Three of the nine known $S D H$ genes ( $S D H 1, S D H 2$, and $S D H 3)$ were expressed in immature and mature leaves and all buds from dormancy to bloom, as well as in all floral organs, except that only $S D H 3$ transcript was found in stamen tissue. Two genes, $S D H 6$ and $S D H 9$, were floral-tissue specific; $S D H 6$ transcript was detected in all floral organs except stamens at full bloom, and $S D H 9$ was only expressed in anthers with pollen. In buds and leaves of young, container-grown trees, $S D H 1$ and $S D H 2$ generally accounted for the majority of total $S D H$ expression. There were generally no effects of rootstock on $S D H$ expression, SDH activity, or sorbitol concentration in leaves, while apical shoot tips on M.9 rootstock exhibited greater SDH activity than those on MM.111 or lateral shoot tips on either rootstock, though $S D H$ expression of apical and lateral shoot tips on M.9 was lower than on MM.111. Prohexadione-Ca reduced apical but not lateral shoot growth, increased apical but not lateral shoot tip sorbitol content, had no effect on SDH activity, and increased SDH1 expression of all shoot tips. D/G treatment reduced shoot growth, sorbitol content, and SDH activity, but increased $S D H 1$ expression of apical shoot tips only and $S D H 2$ expression of lateral shoot tips only. This work indicates that sorbitol and other sugars are abundantly available from dormancy to bloom, that SDH activity increased during this period, and that $S D H$ expression is at least in part developmentally regulated within the individual floral and leaf tissues. In shoot tips and leaves of young trees, $S D H$ transcript level was not correlated with sorbitol availability or SDH activity, suggesting that other factors have significant regulatory effects after SDH expression on SDH activity.
\end{abstract}

Sorbitol is the primary photosynthetic product and the major translocated sugar during the growing season in some species of the Rosaceae family, including apple (Bieleski, 1969; Loescher, 1987; Webb and Burley, 1962). Sorbitol is also an abundant carbohydrate reserve in the xylem sap, with levels at a maximum early in bud development and then declining over time (Hansen and Grausland, 1973, 1978; McQueen et al., 2004). These carbohydrate reserves are remobilized to support initial growth (Oliveira and Priestley, 1988). New photoassimilate gradually replaces the reserve carbohydrate supply once leaves begin maturing in the spring (Corelli Grappadelli et al., 1994; McQueen et al., 2004; Oliveira and Priestley, 1988).

Metabolism of sorbitol by sink tissues in apple is primarily via the action of $\mathrm{NAD}^{+}$-dependent sorbitol dehydrogenase

Received for publication 24 Feb. 2010. Accepted for publication 6 May 2010. ${ }^{1}$ Corresponding author. E-mail: mnosarze@uky.edu.
(NAD ${ }^{+}-\mathrm{SDH}, \mathrm{EC}$ 1.1.1.14), which catalyzes the oxidation of sorbitol to fructose (Loescher, 1987; Yamaguchi et al., 1994; Yamaki and Ishiwaka, 1986). SDH is highly active in young apple leaves and gradually decreases as a leaf matures (Loescher et al., 1982). In the development of apple fruit, SDH also plays an important role. A significant level of SDH activity was found immediately after fruit growth starts, 1 week after bloom, and during the ensuing 5 weeks (Nosarzewski et al., 2004). At the transition from cell division to cell expansion in fruit, and in some cultivars during ripening, $\mathrm{SDH}$ exhibits high levels of activity, and then declines (Park et al., 2002; Yamada et al., 1999; Yamaguchi et al., 1996; Yamaki and Ishiwaka, 1986). In addition to leaves and fruits, SDH activity is also found in other organs, including shoot tips (McQueen and Minchin, 2005; Zhou et al., 2006) and roots (McQueen and Minchin, 2005). In peach (Prunus persica), shoot tip SDH activity was related to sink strength and shoot growth rate (Lo Bianco et al., 1999). 
SDH transcript and protein were present in apple during early fruit development (Nosarzewski and Archbold, 2007; Nosarzewski et al., 2004) and in shoot tips (Zhou et al., 2006). Nine $S D H$ genes were found in the 'Mutsu' apple genome, a triploid cultivar, in contrast to most commercial cultivars, which are diploid, and five $S D H$ genes were expressed in apple fruit, four in seed and three in cortex (Nosarzewski and Archbold, 2007). Park et al. (2002) reported the expression of four $S D H$ genes in apple leaves and fruit of the diploid cultivar Fuji by gene-specific probes, but did not indicate how the expression patterns related to SDH activity. Yamada et al. (1999) reported that the pattern of SDH activity in fruit (i.e., a temporal increase at $104 \mathrm{~d}$ after bloom, a decline to its previous level, and an increase again after $160 \mathrm{~d}$ after bloom) closely corresponded to those of the protein and total $S D H$ mRNA level. Zhou et al. (2006) observed a reduction in $S D H$ transcript levels and activity in transgenic apple shoot tips with reduced sorbitol synthesis.

SDH activity may be positively modulated by sorbitol availability, as shown by defoliation/girdling $(\mathrm{D} / \mathrm{G})$ treatments to deprive apple fruit of sorbitol and by sorbitol feeding of fruit (Archbold, 1999; Berüter and Studer Feusi, 1997) and shoot tips (Zhou et al., 2006). McQueen and Minchin (2005) found that sorbitol had limited metabolism in shoots that had a high sorbitol concentration, suggesting that in shoots, sorbitol may only be translocated. Some evidence suggests that SDH sensitivity to sorbitol availability is regulated at the level of expression (Iida et al., 2004; Yamada et al., 1999; Zhou et al., 2006), but possible posttranslational effects have also been described (Yamaguchi et al., 1996). Cultural practices may also alter $S D H$ expression and SDH activity. During flower bud formation in japanese pear (Pyrus pyrifolia), where partial fragments of five $S D H$ genes were isolated, expression of one $S D H$ gene and SDH activity increased in response to branch shading and bending (Ito et al., 2005).

To understand how sorbitol metabolism is regulated, it is essential to have a comparative profile of $S D H$ expression to a diverse set of conditions. Using real-time polymerase chain reaction (PCR), the relationship of SDH activity with sorbitol availability and $S D H$ transcript levels were investigated for all of the $S D H$ genes expressed in buds and floral tissues of 'Mutsu' apple trees during development from late dormancy to post-bloom, and in leaves and vegetative shoot tips in response to rootstock vigor, growth suppression by application of the gibberellin biosynthesis inhibitor prohexadione- $\mathrm{Ca}$ (ProCa), and assimilate deprivation by $\mathrm{D} / \mathrm{G}$. Three of these treatments-dwarfing rootstock, assimilate deprivation, and growth suppression-reduce shoot growth, and it was our interest to determine if their effects are mediated through an impact on $S D H$ expression and/or activity.

\section{Materials and Methods}

Bud Development STudies. 'Mutsu' and 'Redchief Delicious' apple flower buds and immature leaves were collected from trees set in 1994 at the University of Kentucky Horticultural Research Farm orchard at Lexington in 2004, 2005, and 2006. Buds were harvested at five distinct phases of development (Chaplin and Catlin, 1976; Pratt, 1988): fully dormant (no growth evident), silver tip, half inch green, pink, and full bloom. Immature leaves were also harvested at full bloom. At the half inch green stage, most vegetative tissues were removed, leaving only leaf initials and immature floral clusters. Some flowers at pink and full bloom were separated before freezing into their respective organs: sepals, petals, stamen filaments without anthers, anthers with pollen, and carpels with stigma and styles intact. Following collection and tissue separation if necessary, tissues were immediately frozen in liquid $\mathrm{N}_{2}$ and stored at $-80{ }^{\circ} \mathrm{C}$ storage until further use.

At three stages of bud development in 2006, dormant, half inch green, and full bloom, 5- to 8-cm apical pieces of 'Redchief Delicious' apple shoots ('Mutsu' was not used due to the limited number of trees) subtending flower buds were cut from eight randomly spaced trees within the orchard, wrapped in moistened paper towels, and placed on ice in unsealed plastic bags, and then transported to the laboratory for xylem sap collection. Shoots were re-cut, and xylem sap was expressed from each using a pressure bomb (PMS Instruments, Albany, OR), making multiple composite samples of sap from three to five shoots from each of two to three trees.

ROOTSTOCK AND GROWTH MANIPULATION STUDIES. This work was carried out using 2-year-old 'Mutsu' apple trees grafted on two contrasting rootstocks, the moderately vigorous rootstock MM.111 and the dwarfing rootstock M.9 (Tworkoski and Miller, 2007), in 2008. Twenty trees on each rootstock were grown in 7.6-L plastic containers in MetroMix 560 (Scotts, Marysville, $\mathrm{OH}$ ) outdoors under natural conditions. During the dormant season, they were pruned to a uniform height and number of lateral shoots within rootstock. They were irrigated once or twice weekly as needed, and nutrients were provided using Peters Professional Peat-Lite Special (Scotts) with $20 \mathrm{~N}-$ $8.8 \mathrm{P}-16.6 \mathrm{~K}$ at $200 \mathrm{mg} \cdot \mathrm{L}^{-1} \mathrm{~N}$ every other week through the end of the study. Pesticides were applied as needed.

In early June, one apical and two lateral shoots were selected on each container-grown tree, and these were measured from base of the new growth to the shoot tip. Ten MM.111 trees were sprayed with ProCa [27.5\% a.i. (Apogee; BASF, Research Triangle Park, NC)], a gibberellin (GA) biosynthesis inhibitor that is commercially used to limit apple tree growth, at 125 $\mathrm{mg} \cdot \mathrm{L}^{-1}$ a.i. with $0.05 \%(\mathrm{v} / \mathrm{v})$ Silwet (Setre Chemical Co., Memphis, TN). The apical shoot and one lateral shoot on 10 M.9 trees were subjected to a $\mathrm{D} / \mathrm{G}$ treatment by removing a 5-mm-wide strip of bark at the shoot base and all the leaves on the shoot except the youngest emerging leaves (Archbold, 1999). For both groups of treated trees, 10 trees served as controls. Shoot length was measured and leaves were removed from the shoot tip when they reached $\approx 50 \%$ of their mature size every week. Three weeks after ProCa application and D/G treatment, shoot tips consisting of the apical meristem and all of the youngest folded leaves were excised and immediately frozen in liquid nitrogen before storage at $-80{ }^{\circ} \mathrm{C}$. In addition to comparing shoot tip position of control trees from samples described above, immature and mature leaves were also sampled from the controls of both rootstocks and frozen for subsequent analyses.

Xylem SAP CARbohydrate anAlyses. High-performance liquid chromatography (HPLC) was used to analyze soluble sugars in three replicate composite xylem sap samples collected with dormant, half inch green, and full bloom buds. For HPLC of sugars using pulsed electrochemical detection (HPLC-PED) analysis, xylem sap samples were diluted 1:50 with Milliporepurified water and used directly. Sorbitol was quantified using a BioLC (Dionex, Sunnyvale, CA), with degassed NaOH (1 M) and degassed water as mobile phase $(52 \%, \mathrm{v} / \mathrm{v})$, a sample loop 
volume of $25 \mu \mathrm{L}$, and on a $4 \mathrm{~m} \times 250 \mathrm{~mm}$ CarboPac MA1 analytical column (Dionex) at a flow rate of $0.4 \mathrm{~mL} \cdot \mathrm{min}^{-1}$. Neutral sugars were quantified in the same samples on the same system using a 4-mm $\times 250-\mathrm{mm}$ CarboPac PA1 column (Dionex) with degassed $\mathrm{NaOH}(200 \mathrm{~mm})$ and degassed water as mobile phase $(9 \%-91 \%, \mathrm{v} / \mathrm{v})$ at a flow rate of $1 \mathrm{~mL} \cdot \mathrm{min}^{-1}$. A quantitative determination of the major sugars detected, sorbitol, glucose, fructose, and sucrose, was made by comparing the sample results with an external standard, and the xylem sap concentration of each was calculated.

Shoot TIP AND LEAF CARboHydRATE ANALYSES. Frozen leaf or shoot tip $(\approx 0.03 \mathrm{~g})$ was ground into powder with a mortar and pestle, and was extracted three times with $4 \mathrm{~mL}$ of $40 \%$ methanol each time. After centrifugation at $2000 g_{n}$ for 10 min, the combined supernatant was evaporated to dryness under $\mathrm{N}_{2}$. The dry residues were re-eluted with $100 \mu \mathrm{L}$ of pyridine (containing $50 \mathrm{mg} \cdot \mathrm{mL}^{-1}$ hydroxylamine hydrochloride), ribitol was added as an internal standard, and they were heated for 30 min at $80^{\circ} \mathrm{C}$. The cooled samples were silylated with $100 \mu \mathrm{L}$ of BSTFA (Pierce, Rockford, IL), heated for $10 \mathrm{~min}$ at $80^{\circ} \mathrm{C}$, and used for sugar measurement.

Sorbitol, fructose, glucose, and sucrose were determined by gas chromatography (HP 5890; Agilent Technologies, Wilmington, DE) equipped with a flame ionization detector (FID) and a 30-m $\times 0.53-\mathrm{mm}$ i.d. $\times 0.5-\mu \mathrm{m}$ liquid phase Rtx-1701 column (Restek, Bellefonte, PA) with $\mathrm{N}_{2}$ as the carrier gas. Injector and detector temperatures were set at 170 and $270{ }^{\circ} \mathrm{C}$, respectively, with runs at $170{ }^{\circ} \mathrm{C}$ for $12 \mathrm{~min}$, and an increase of $10{ }^{\circ} \mathrm{C}$ per minute to $270{ }^{\circ} \mathrm{C}$. Quantitative values were derived from peak areas relative to the ribitol internal standard.

SDH ACTIVITY MEASUREMENT. SDH enzyme was extracted as described by Nosarzewski and Archbold (2007) by grinding $\approx 0.2 \mathrm{~g}$ of frozen tissue in $2 \mathrm{~mL}$ of $0.5 \mathrm{M}$ Tris- $\mathrm{HCl}(\mathrm{pH} \mathrm{7})$, containing $0.2 \%$ (w/v) Na-ascorbate, $0.1 \%$ (v/v) Triton X100 (Sigma-Aldrich, St. Louis), and $1 \%(\mathrm{w} / \mathrm{v})$ PVPP (Sigma-Aldrich). After centrifugation at $12,000 g_{n}$ for $20 \mathrm{~min}$, the supernatant was desalted using a Sephadex G-50 column (Sigma-Aldrich). All of the procedures were carried out at $4{ }^{\circ} \mathrm{C}$ and held on ice. There were three replicate extractions per tissue and treatment.

The SDH activity assay mixture contained $0.45 \mathrm{~mL}$ of desalted extract in $0.8 \mathrm{~mL}$ of $30 \mathrm{~mm}$ Tris- $\mathrm{HCl}$ (pH 9.6), $1 \mathrm{~mm} \mathrm{NAD}^{+}$, and $275 \mathrm{~mm}$ sorbitol. Activity of SDH was assayed by measuring the continuous reduction of $\mathrm{NAD}^{+}$by the change in absorbance at $340 \mathrm{~nm}$ for $10 \mathrm{~min}$. The Bradford assay was used to quantify protein. Enzyme activity is reported as nano- moles NADH per milligram of protein per minute and/or nanomoles NADH per gram fresh weight (FW) per minute.

Western ANALYSES. Western blots were performed using the ImmunoPure ABC Phosphatase Staining Kit (Pierce) at room temperature as described in Nosarzewski et al. (2004).

REVERSE TRANSCRIPTION (RT)-PCR ANALYSES. RT-PCR analyses were performed to detect which one of nine $S D H$ genes was expressed in sampled tissues. Total RNA was isolated from samples of dormant, half inch green, and full bloom stage tissues, and from the separate floral organs at full bloom, using an RNase Plant Easy (Qiagen, Valencia, CA). Total RNA isolated from the above tissues was pretreated with DNase I using a kit (DNA-free; Ambion, Austin, TX) according to the manufacturer's protocol. The first-strand cDNA for RTPCR analysis was synthesized with oligo $(\mathrm{dT})_{18}$ primers using 1 $\mu \mathrm{g}$ of total RNA and SUPERSCRIPT III (Invitrogen, Carlsbad, $\mathrm{CA})$ at $50^{\circ} \mathrm{C}$ for $1 \mathrm{~h}$. The reaction was ended $\left(75^{\circ} \mathrm{C}, 15 \mathrm{~min}\right)$ and treated with RNase cocktail (Ambion) at $37^{\circ} \mathrm{C}$ for $20 \mathrm{~min}$. PCR was performed on $2 \mu \mathrm{L}$ of first-strand cDNA, using genespecific primers for all nine $S D H$ mRNA species at 40 PCR cycles (Table 1) (Nosarzewski and Archbold, 2007). The annealing temperatures used for those reactions were the same as listed in Nosarzewski and Archbold (2007), except SDH6 gene-specific primers, for which the annealing temperature was increased from 65 to $72{ }^{\circ} \mathrm{C}$. Amplicons were isolated on $1 \%$
Table 1. Forward (F) and reverse (R) primers, annealing temperatures, and expected amplicon sizes of nine apple sorbitol dehydrogenase $(\mathrm{SDH})$ genes for RT-PCR.

\begin{tabular}{|c|c|c|c|}
\hline Gene & Primers & $\begin{array}{l}\text { Annealing } \\
\text { temp }\left({ }^{\circ} \mathrm{C}\right)\end{array}$ & $\begin{array}{c}\text { Amplicon } \\
\text { size (bp) }\end{array}$ \\
\hline \multirow[t]{2}{*}{$\overline{S D H 1}$} & F 5'-CTCCAAATAATGGTTGTC-3' & 50 & 281 \\
\hline & R 5'-CAACTAACGTTTCTCAGAA-3' & & \\
\hline \multirow[t]{2}{*}{$\mathrm{SDH} 2$} & F 5'-GCATCAGCTGCGCACATT-3' & 55 & 650 \\
\hline & R 5'-CAAAAACTCAAGGCAAAGC-3' & & \\
\hline \multirow[t]{2}{*}{$\mathrm{SDH} 3$} & F 5'-ACGTGAAGCATCTGGTTT-3' & 55 & 407 \\
\hline & R 5'-TCCCAGAGACTTGGCCAC-3' & & \\
\hline \multirow[t]{2}{*}{$\mathrm{SDH} 4$} & F 5'-TCGGCGAGCCAATGTTGA-3' & 60 & 375 \\
\hline & R 5'-GCAGCGGGAGTCAGAGGC-3' & & \\
\hline \multirow[t]{2}{*}{ SDH5 } & F 5'-AGGCCGCTACAATCTCTGT-3' & 55 & 611 \\
\hline & R 5'-CGAGGAGTTCCAAGCTT-3' & & \\
\hline \multirow[t]{2}{*}{ SDH6 } & F 5'-TCAGCAGTGCAAAGGAGGGCAG-3' & 72 & 367 \\
\hline & R 5'-CCCGAAAGCAAGAGCGGCCAAA-3' & & \\
\hline \multirow[t]{2}{*}{$\mathrm{SDH7}$} & F 5' -CGTCAGCAGTGCAAAGGAGGGCAG-3' & 65 & 283 \\
\hline & R 5'-TCCGAAAGCACGAGCAGCCAGC-3' & & \\
\hline \multirow[t]{2}{*}{ SDH8 } & F 5'-TTGCTTTAAATTGCCAA-3' & 50 & 323 \\
\hline & R 5'-TTTCCAGTGTAGGTGG-3' & & \\
\hline \multirow[t]{2}{*}{ SDH9 } & F 5'-AAGTTTTCGCCACCCCC-3' & 60 & 235 \\
\hline & R 5'-CCCGAAAGCACGAGCGGT-3' & & \\
\hline
\end{tabular}

Table 2. Forward (F) and reverse (R) primers, annealing temperatures, and expected amplicon sizes of apple sorbitol dehydrogenase genes for real-time PCR.

\begin{tabular}{|c|c|c|c|}
\hline Gene & Primers & $\begin{array}{l}\text { Annealing } \\
\text { temp }\left({ }^{\circ} \mathrm{C}\right)\end{array}$ & $\begin{array}{l}\text { Amplicon } \\
\text { size (bp) }\end{array}$ \\
\hline \multirow{2}{*}{$\overline{S D H 1}$} & F 5'-CATGAGGTGTGTAGATTTTATA-3' & 55 & 157 \\
\hline & R 5'-GCAGAGGTTGCATCGCTT-3' & & \\
\hline \multirow[t]{2}{*}{$\mathrm{SDH} 2$} & F 5'-TGCCAGCAGTGCAAGGGC-3' & 67 & 121 \\
\hline & R 5'-ATTTAAAGCACAGATCCGCG-3' & & \\
\hline \multirow[t]{2}{*}{ SDH3 } & F 5'-CGACGTGAAGCATCTGGTTT-3' & 65 & 161 \\
\hline & R 5'-GCACAATCTGGTTAGCCAAG-3' & & \\
\hline
\end{tabular}


(w/v) agarose gels and were subjected to ethidium bromide staining. An additional control to insure primer gene specificity was performed for SDH6 gene-specific primers because at the $65{ }^{\circ} \mathrm{C}$ annealing temperature, those primers could also recognize $\mathrm{SDH} 2$ cDNA (Nosarzewski and Archbold, 2007). The annealing temperature was increased to $72{ }^{\circ} \mathrm{C}$, and the SDH6 gene-specific primer recognition toward $\mathrm{SDH} 2 \mathrm{cDNA}$ was eliminated.

Real-time PCR. Real-time PCR was performed to characterize the relative expression of $S D H 1, S D H 2$, and $S D H 3$ in sampled tissues. Total RNA was extracted as described above. A High-Capacity cDNA Reverse Transcription kit (Applied Biosystems, Foster City, CA) was used to synthesize first-cDNA strand from $2 \mu \mathrm{g}$ of total RNA in a final volume of $20 \mu \mathrm{L}$, containing $2 \mu \mathrm{L}$ of $10 \times$ RT buffer, $2 \mu \mathrm{L}$ of $10 \times$ Random Primers, $0.8 \mu \mathrm{L}$ of $100 \mathrm{~mm}$ dNTP Mix, and $1 \mu \mathrm{L}$ of MultiScribe $^{\mathrm{TM}}$ reverse transcriptase (Applied Biosystems) at $37{ }^{\circ} \mathrm{C}$ for $2 \mathrm{~h}$. The reaction was ended $\left(85^{\circ} \mathrm{C}, 5 \mathrm{~min}\right)$ and real-time PCR was performed using a StepOne Real-Time PCR system (Applied Biosystems). PCR was performed on $1 \mu \mathrm{L}$ of first-strand cDNA using Fast SYBR Green PCR Master Mix (Applied Biosystems) and gene-specific primers (500 nmol) for three $S D H$ mRNA species at 40 PCR cycles (activation step at $95^{\circ} \mathrm{C}$ for $20 \mathrm{~s}$, 40 cycles including $3 \mathrm{~s}$ of denaturation at $95{ }^{\circ} \mathrm{C}$ and $30 \mathrm{~s}$ of annealing/extension at temperatures listed in Table 2). The $\beta$-TUBULIN (GenBank accession no. Q43209, locus tag At5g62690) was used as the endogenous control for normalization of the quantity of total RNA present in the sample. Three replicates of real-time PCR runs were performed for each sample. To determine the absolute number of target transcripts, $S D H 1, S D H 2$, and SDH3 cloned plasmids (Nosarzewski et al., 2004) were used to generate a calibration curve by plotting the threshold cycle against the known copy number for each plasmid template diluted from $10^{3}$ to $10^{9}$ copies. To correct for the difference in RNA quality and quantity between samples, data were normalized to the level of $\beta-T U B U L I N$ transcript. Standard curves for target genes and $\beta-T U B U L I N$ at different annealing temperatures are listed below.

$\mathrm{SDH} 1\left(55^{\circ} \mathrm{C}\right) \mathrm{Ct}$ value $=(-3.8923 \times \log$ of copy number $)$

$$
+50.611\left(\mathrm{R}^{2}=0.984\right)
$$

$\beta-T U B U L I N\left(55^{\circ} \mathrm{C}\right) \mathrm{Ct}=$

$(-3.2813 \times \log$ of copy number $)+40.233\left(\mathrm{R}^{2}=0.984\right)$

$\mathrm{SDH} 2\left(67^{\circ} \mathrm{C}\right) \mathrm{Ct}$ value $=(-3.5981 \times \log$ of copy number $)$

$$
+44.985\left(\mathrm{R}^{2}=0.9881\right)
$$

$\beta-T U B U L I N\left(67^{\circ} \mathrm{C}\right) \mathrm{Ct}=$

$(-3.4112 \times \log$ of copy number $)+41.29\left(\mathrm{R}^{2}=0.9968\right)$
$\mathrm{SDH} 3\left(65^{\circ} \mathrm{C}\right) \mathrm{Ct}$ value $=(-3.3204 \times \log$ of copy number $)$

$$
+39.156\left(\mathrm{R}^{2}=0.9983\right)
$$

$\beta-T U B U L I N\left(65^{\circ} \mathrm{C}\right) \mathrm{Ct}=(-3.3912 \times \log$ of copy number $)$

$$
+41.027\left(\mathrm{R}^{2}=0.984\right)
$$

Statistical ANALysis. Data from the growth manipulation studies were analyzed by analysis of variance (ANOVA) for main effects of the treatments. Means were compared by Fisher's least significant difference at $P<0.05$.

\section{Results}

Bud DEVELOPMENT STUdies. SDH activity was detected in intact dormant and silver tip buds as well as in the carpels of the half inch green, pink, and full bloom samples. SDH activity per milligram of protein (Fig. 1A) was low and similar in dormant and silver tip buds, but subsequently increased 5-fold during the remainder of development. SDH activity of 'Mutsu' apple flower buds at each developmental stage was similar to 'Redchief Delicious' SDH activity within one standard deviation 
(data not shown). Western analyses confirmed the presence of SDH protein in each developmental stage (Fig. 1B) by detection of a distinct $37-\mathrm{kDa}$ band.

The sorbitol concentration was 3- to 6-fold higher than that of glucose or fructose in shoots subtending buds at each stage of development (Fig. 2). Sucrose was only detected at the dormant stage at a xylem sap concentration similar to those of glucose and fructose. Sorbitol concentration appeared highest at the half inch green stage, though was not statistically greater as variability among samples was high. Glucose and fructose in half inch green and full bloom tissues were greater than in dormant tissue $(P \leq 0.05)$, but they were still considerably lower than sorbitol concentration.

$S D H 1, S D H 2$, and $S D H 3$ were expressed in immature leaves and in flower buds throughout development (Figs. 3 and 4). Additionally, in dormant, half inch green, and king bloom flower buds, SDH6 transcript was detected (Fig. 3). SDH9 was only expressed at full bloom. $S D H 1, S D H 2$, and $S D H 3$ were expressed in all floral organs (sepal, petal, carpel, and stamen) at full bloom (Fig. 4). SDH6 was also expressed in all floral organs except stamens, in contrast to $S D H 9$ for which expression was limited to anthers with pollen only. Interestingly, $\mathrm{SDH} 3$ was the only $\mathrm{SDH}$ gene expressed in stamen filaments (Fig. 4).

ROOTSTOCK AND GROWTH MANIPULATION STUDIES. Sorbitol accounted for $68 \%$ to $76 \%$ of the total soluble carbohydrate (the sum of sorbitol, glucose, fructose, and sucrose) in apple leaves and shoot tips (data not shown). Sorbitol concentration in immature leaves was significantly lower than that in mature leaves (Table 3 ). However, protein concentration was nearly 2 -fold greater and SDH activity per milligram of protein was 20 - to 37-fold greater and per gram of FW was 60- to 70-fold greater in immature than mature leaves. In immature and mature leaves, $S D H 1, S D H 2$, and $S D H 3$ were expressed and accounted for $>70 \%, 5 \%$ to $26 \%$, and $\leq 10 \%$, respectively, of total $S D H$ expression. Mature leaves had higher total $S D H$ and $S D H 1$ transcript levels than immature leaves. Rootstock had no effect on leaf sorbitol or protein content, or SDH activity, but $S D H$ expression was generally higher on M.9 than on MM.111. There was a leaf age by rootstock interaction on sorbitol content and $S D H$ expression of all but SDH1.

Apical shoot tips exhibited higher sorbitol levels, lower protein, higher SDH activity, and lower $S D H$ expression than lateral shoot tips (Table 3 ). There were significant rootstock effects on some of these traits, with significant shoot tip position by rootstock interactions as well. Notably, apical shoot tips on M.9 exhibited much greater SDH activity than lateral shoot tips on the same trees and shoot tips from MM.111 trees, while lateral shoot tips on M.9 rootstock showed greater $S D H 1, S D H 2$, and total gene expression than lateral shoot tips from the same trees, and greater expression than from all shoot tips on MM.111. Apical but not lateral shoot growth on MM.111 was reduced by ProCa (Table 4). ProCa treatment signif-

B icantly increased sorbitol concentration, most notably in apical shoot tips. ProCa did not affect shoot tip protein concentration (data not shown) or SDH activity. SDH1 and total $S D H$ expression in apical but not lateral shoot tips increased in response to ProCa, with significant position, treatment, and position by treatment effects. However, neither $\mathrm{SDH} 2$ nor SDH3 transcript abundance were affected.

The D/G treatment reduced apical and lateral shoot growth (Table 4). The treatment also reduced sorbitol concentration, more so in lateral than apical shoot tips, had no effect on shoot tip protein concentration (data not shown), and significantly reduced SDH activity, mostly in apical shoot tips. Defoliation/

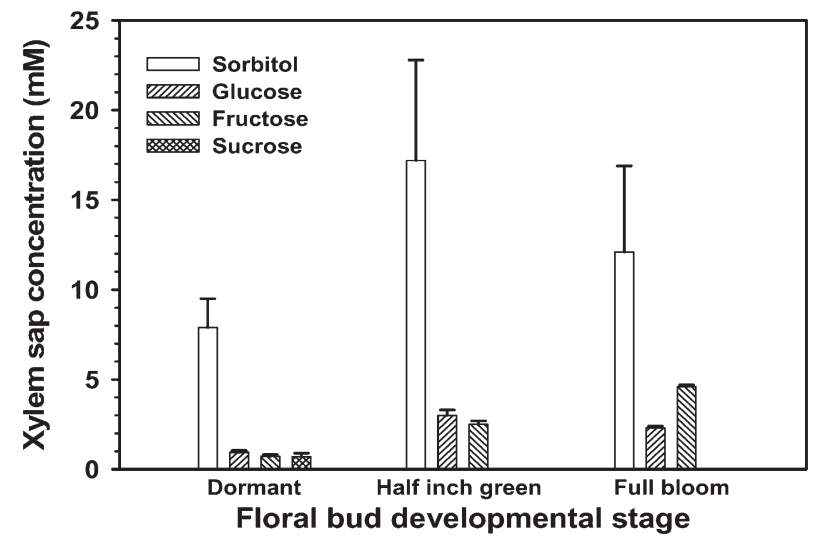

Fig. 2. Xylem sap soluble sugar levels at the dormant, half inch green and full bloom stages of apple floral buds.
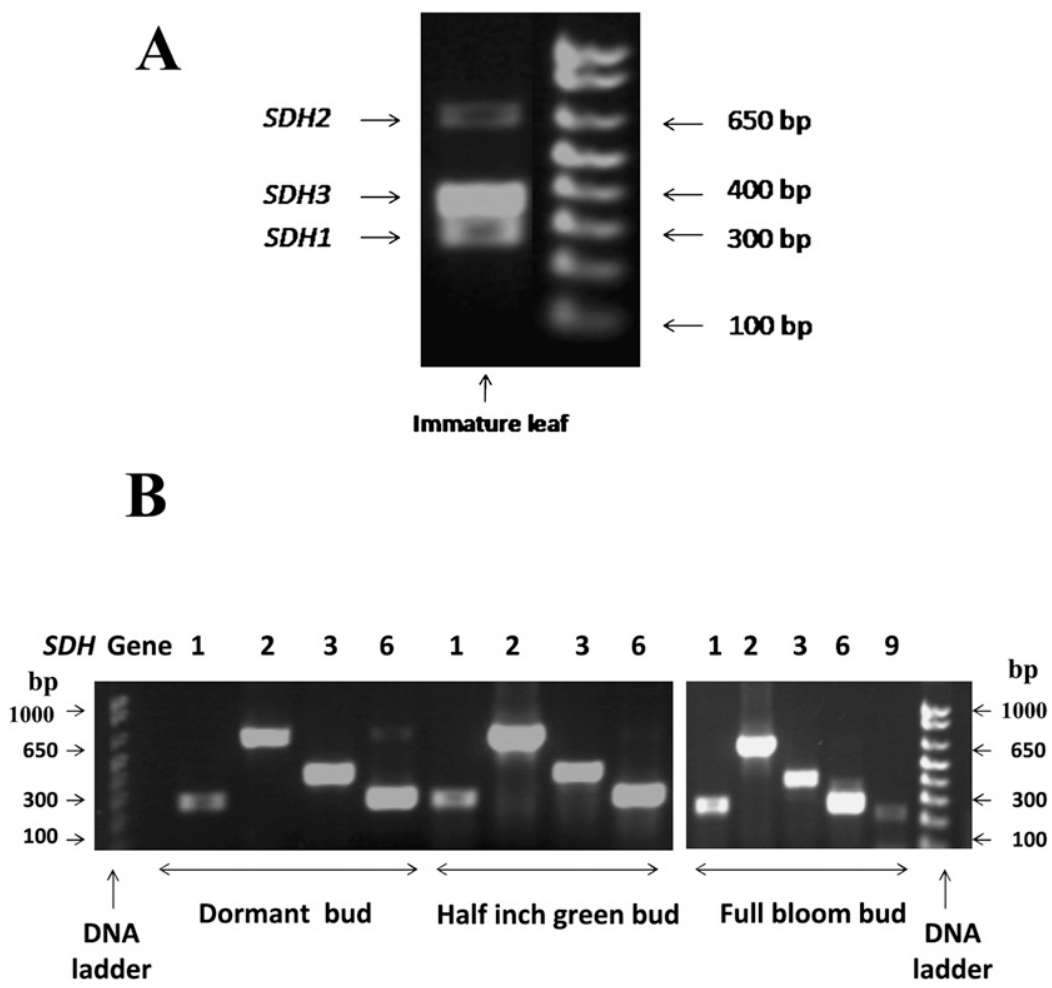

Fig. 3. RT-PCR analyses of RNA transcripts from (A) immature leaves and (B) developing buds of apple. RT-PCR products were obtained at 40 reaction cycles using gene-specific primers. 

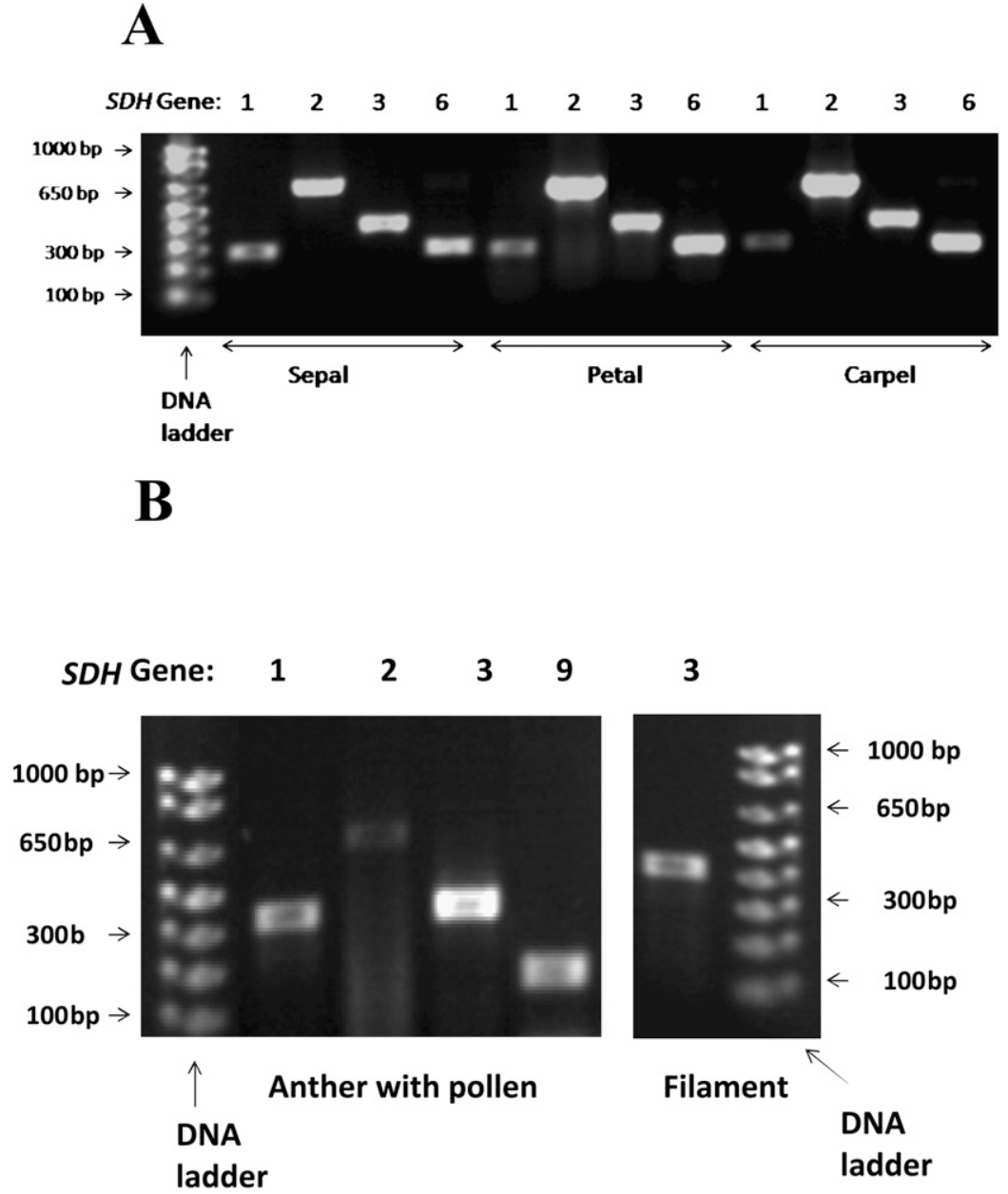

Fig. 4. RT-PCR analysis of RNA transcripts extracted from (A) sepal, petal, and carpel tissues, and (C) anther and filament tissues of stamen, from 'Mutsu' apple flowers at full bloom. RT-PCR products were obtained at 40 reaction cycles using gene-specific primers for $S D H$ cDNAs.

girdling had no effect on $S D H$ expression in apical shoot tips, but decreased $S D H 1$ transcript and increased $S D H 2$ transcript in lateral tips. Total $S D H$ transcript abundance was unaffected by $\mathrm{D} / \mathrm{G}$.

\section{Discussion}

SDH activity at the dormant and silver tip stages of apple floral bud development was lower than in apple fruit during the first 5 weeks of fruit development (Nosarzewski and Archbold, 2007). Because these buds (dormant and silver tip) were extracted intact and contained floral and vegetative tissues, SDH activity was a composite of these tissues. SDH activity per milligram of protein from the half inch green, pink, and full bloom stages (Fig. 1B) had increased and reached levels comparable with that of developing cortex tissue during early fruit development (Nosarzewski and Archbold, 2007). The high levels of SDH activity during the final stages of apple flower bud development may maximize the utilization of sorbitol, which was abundant in the expressed sap (Fig. 2). There was no correlation between SDH activity and sorbitol level, although prior studies have shown that fruit cortex SDH activity can be influenced by sorbitol availability (Archbold, 1999).
Three (SDH1, SDH2, and $S D H 3)$ of nine $S D H$ genes identified in apple were expressed in leaves in the present work (Fig. 3). Park et al. (2002) found four SDH isoforms in immature apple leaves. Thus, it is possible that Park et al. studied an isoform for which we lack a probe. All $S D H$ genes expressed in flower buds (SDH1, SDH2, SDH3, SDH6, and $S D H 9$; Figs. 3 and 4 ) were also found in apple fruit during early development (Nosarzewski and Archbold, 2007). The expression of $S D H$ genes varied depending on the fruit tissue. Expression of $S D H 2$ was cortex-specific, that of SDH6 and SDH9 were seed-specific, and $S D H 1$ and $S D H 3$ were shared by both tissues. Thus, immature leaves exhibited the same $S D H$ gene expression as fruit cortex tissue. In addition to $S D H 1, S D H 2$, and $S D H 3$, developing flower buds and floral organs also expressed two other genes, SDH6 and SDH9. SDH6 expression was floral-specific because transcript was found in flower buds throughout development and in all flower organs except stamen during the final stage of development. Though sepals may be considered modified leaves, they differed from immature leaves by the added expression of SDH6 in addition to $S D H 1, S D H 2$, and $S D H 3$. Because the seedcoat is derived from maternal tissue, SDH6 expression likely started during flower bud development and continued during seed development. SDH9 transcript, found in anthers with pollen during the last stage of flower bud development, was also expressed in seed tissues. Two genes, $S D H 1$ and $S D H 3$, were expressed by all tissues, with no tissue specificity. These results clearly demonstrated that $S D H$ genes were expressed in a tissue-specific manner.

In 'Mutsu' leaf tissue on both rootstocks, sorbitol concentration increased and SDH activity decreased when leaves matured (Table 3). This is generally consistent with prior studies showing that high SDH activity was primarily in immature apple leaves only (Loescher et al., 1982; Negm and Loescher, 1979; Zhou et al., 2006). In our work, SDH transcript abundance was not correlated to the SDH activity of leaves.

In shoot tips, SDH activity ranged from 69 to $173 \mathrm{nmol}$ $\mathrm{NADH}$ per minute per gram of $\mathrm{FW}$, consistent with the range for shoot tips reported by McQueen and Minchin (2005) and Zhou et al. (2006), who found 10 to $400 \mathrm{nmol}$ NADH per minute per gram of FW in apple. The apical shoot on M.9 grew more than the lateral shoot, as well as apical and lateral shoots on MM.111, and had a greater SDH activity as well (Table 4). Thus, SDH activity may be an indication of sink strength and/or demand with high levels in the most rapidly developing leaves and shoot tips as described by Lo Bianco et al. (1999) for peach. As with leaves, transcript abundance was not related to SDH activity of shoot tips.

ProCa is used to suppress vigorous apple tree growth, thus we hypothesized that it may reduce shoot tip sink demand, SDH 
Table 3. Effect of MM.111 (moderately vigorous) and M.9 (dwarfing) apple rootstocks on sorbitol and protein concentrations, sorbitol dehydrogenase (SDH) activity, and SDH gene expression in immature versus mature leaves and apical versus lateral shoot tips of 'Mutsu' apple.

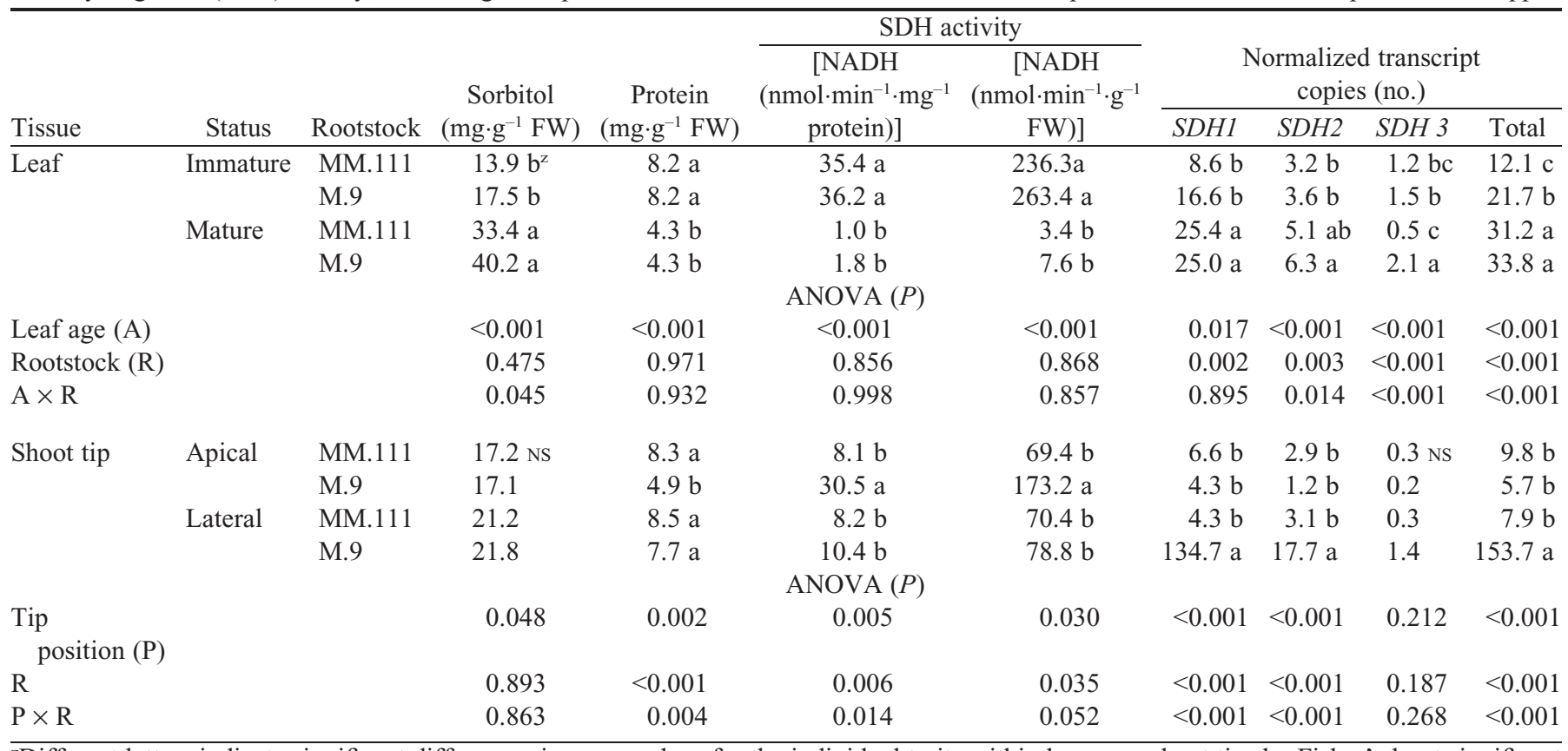

${ }^{\mathrm{z}}$ Different letters indicate significant differences in mean values for the individual traits within leaves or shoot tips by Fisher's least significant difference at $P<0.05$. Ns indicates no significant differences.

Table 4. Shoot growth, sorbitol concentration, sorbitol dehydrogenase (SDH) activity, and SDH gene expression in shoot tips of 'Mutsu' apple on MM.111 rootstock 3 weeks after prohexadione-Ca (ProCa) application and on M.9 rootstock 3 weeks after defoliation/girdling (D/G) treatment.

\begin{tabular}{|c|c|c|c|c|c|c|c|c|c|}
\hline \multirow{3}{*}{$\begin{array}{l}\text { Shoot } \\
\text { position }\end{array}$} & \multirow[b]{3}{*}{ Treatment } & \multirow{3}{*}{$\begin{array}{l}\text { Shoot } \\
\text { growth } \\
(\mathrm{cm})^{\mathrm{z}}\end{array}$} & \multirow{3}{*}{$\begin{array}{c}\text { Sorbitol } \\
\left(\mathrm{mg} \cdot \mathrm{g}^{-1} \mathrm{FW}\right)\end{array}$} & \multicolumn{2}{|c|}{ SDH activity } & \multirow{2}{*}{\multicolumn{4}{|c|}{$\begin{array}{c}\text { Normalized transcript } \\
\text { copies (no.) }\end{array}$}} \\
\hline & & & & \multirow{2}{*}{$\begin{array}{c}\text { [NADH } \\
\left(\mathrm{nmol} \cdot \mathrm{min}^{-1} \cdot \mathrm{mg}^{-1}\right. \\
\text { protein })]\end{array}$} & \multirow{2}{*}{$\begin{array}{c}\text { [NADH } \\
\left(\mathrm{nmol} \cdot \mathrm{min}^{-1} \cdot \mathrm{g}^{-1}\right. \\
\mathrm{FW})]\end{array}$} & & & & \\
\hline & & & & & & $S D H 1$ & $\mathrm{SDH} 2$ & $\mathrm{SDH} 3$ & Total \\
\hline \multirow[t]{2}{*}{ Apical } & Control & $3.3 \mathrm{a}^{\mathrm{y}}$ & $17.2 \mathrm{~b}$ & $8.1 \mathrm{NS}$ & $69.5 \mathrm{NS}$ & $6.6 \mathrm{~b}$ & $2.9 \mathrm{NS}$ & $0.3 \mathrm{NS}$ & $9.8 \mathrm{~b}$ \\
\hline & ProCa & $1.8 \mathrm{~b}$ & $27.2 \mathrm{a}$ & 7.5 & 63.2 & $18.7 \mathrm{a}$ & 2.7 & 0.3 & $20.8 \mathrm{a}$ \\
\hline \multirow[t]{2}{*}{ Lateral } & Control & $2.4 \mathrm{ab}$ & $21.2 \mathrm{ab}$ & 8.2 & 70.4 & $4.3 \mathrm{~b}$ & 3.1 & 0.3 & $7.9 \mathrm{~b}$ \\
\hline & & & & ANOVA $(P)$ & & & & & \\
\hline Shoot position $(\mathrm{P})$ & & 0.689 & 0.643 & 0.747 & 0.897 & $<0.001$ & 0.632 & 0.905 & $<0.001$ \\
\hline Treatment (T) & & 0.382 & 0.006 & 0.649 & 0.520 & $<0.001$ & 0.275 & 0.632 & $<0.001$ \\
\hline \multirow[t]{2}{*}{$\mathrm{P} \times \mathrm{T}$} & & 0.040 & 0.738 & 0.583 & 0.975 & 0.009 & 0.972 & 0.431 & 0.013 \\
\hline & & & & 'Mutsu'/M.9 & & & & & \\
\hline Lateral & & & & ANOVA $(P)$ & & & & & \\
\hline $\mathrm{P}$ & & $<0.001$ & 0.074 & 0.006 & 0.106 & $<0.001$ & $<0.001$ & $<0.001$ & $<0.001$ \\
\hline $\mathrm{T}$ & & $<0.001$ & $<0.001$ & $<0.001$ & $<0.001$ & 0.579 & 0.076 & 0.627 & 0.835 \\
\hline $\mathrm{P} \times \mathrm{T}$ & & 0.005 & 0.544 & 0.101 & 0.012 & 0.010 & $<0.001$ & 0.129 & 0.164 \\
\hline
\end{tabular}

${ }^{\mathrm{z}}$ Shoot growth in the 8-d period preceding sampling.

${ }^{y}$ Different letters within rootstock and treatment groups indicate significant differences in mean values within a column by Fisher's least significant difference at $P<0.05$. Ns indicates no significant differences.

activity, and/or SDH expression. ProCa increased sorbitol concentration in the apical shoot tips, similar to the effect of paclobutrazol, another GA biosynthesis inhibitor (Wang et al., 1986), which increased carbohydrates in all parts of apple trees.
Though ProCa increased sorbitol concentration, it did not affect SDH activity in apical or lateral tips. Li and Li (2007) showed that when there was sufficient water supply, GA concentration and SDH activity in apple leaves did not show a correlation 
$(r=0.09)$, while under water stress, a positive correlation between the two was established $(r=0.34-0.46)$. In addition, Zhang et al. (2007) reported that SDH activity in the flesh of GAtreated fruit was significantly greater than that in control fruit between 7 and $56 \mathrm{~d}$ after treatment, but no significant differences between treatments were observed in the core. These reports imply that the effect of ProCa on SDH activity might be more apparent in stress conditions and may also be tissue specific. Though SDH1 transcript in the apical shoot tip was induced by ProCa, there was no corollary effect on SDH activity.

Blocking the assimilate supply to the shoot tip by defoliation of a shoot and girdling the phloem to isolate the tip from the remainder of the tree caused a decreased shoot growth, sorbitol concentration, and apical but not lateral SDH activity (Table 4). The same isolation of fruit caused similar responses (Archbold, 1999; Berüter and Studer Feusi, 1997), while suppressed sorbitol synthesis in leaves of transgenic apple lines (Teo et al., 2006; Zhou et al., 2006) reduced shoot tip SDH activity. However, the treatment effects on SDH activity were generally not matched by effects on $S D H 1, S D H 2$, and total $S D H$ expression. Interestingly, $S D H 1$ transcript decreased and $S D H 2$ transcript increased in the same lateral shoot tips in response to $\mathrm{D} / \mathrm{G}$ treatment, perhaps resulting in the lack of the treatment effect on SDH activity.

In conclusion, the present work is the first comprehensive study of tissue-specific expression of $S D H$ genes in apple floral and vegetative tissues from dormancy to full bloom and in response to vegetative growth manipulation. Increasing SDH activity and the abundance of available sorbitol from reserves indicate that SDH plays a primary role in carbohydrate metabolism during the budbreak to bloom of apple flower bud development. SDH activity in 'Mutsu' apple shoot tips and leaves resulted from expression of three of nine known $S D H$ genes in 'Mutsu', $S D H 1, S D H 2$, and $S D H 3$, with $S D H 1$ and $S D H 2$ providing the bulk of the transcript present. Relationships among sorbitol availability, extractable SDH activity, and $S D H$ transcript levels changed with tissue type and age, rootstock, and vegetative growth manipulation, but SDH activity and $S D H$ transcript levels showed no clear relationships. Notable examples included a more than 20 -fold greater SDH activity in young versus old leaves but a $>35 \%$ lower total $S D H$ transcript level of young leaves; a 2.5- to 3.7-fold greater SDH activity in apical shoot tips on M.9 than on MM.111, but about $42 \%$ less total SDH transcript; 19-fold greater total SDH transcript of lateral shoot tips on M.9 versus MM.111 rootstock without a difference in SDH activity; and no change in SDH activity of apical shoot tips on MM.111 after ProCa treatment, but a 2 -fold increase in total $S D H$ transcript level. Prior reports of correlations between $S D H$ transcript levels and activity have not employed endogenous reference standards such as $\beta$-TUBULIN as used in the present work, thus the accuracy of those reports is uncertain. From the present results, it appears that other factors, possibly including regulation of translation and posttranslational modification(s) of $\mathrm{SDH}$, must have also been influenced by the treatments in ways not yet revealed that impacted SDH activity. Thus, though developmental and horticultural factors may alter $S D H$ expression and/or SDH activity, it is clear that there is not a simple correlation between $S D H$ gene expression and SDH activity.

\section{Literature Cited}

Archbold, D.D. 1999. Carbohydrate availability modifies sorbitol dehydrogenase activity of apple fruit. Physiol. Plant. 105:391-395.
Berüter, J. and M.E. Studer Feusi. 1997. The effect of girdling on carbohydrate partitioning in the growing apple fruit. J. Plant Physiol. 151:277-285.

Bieleski, R.L. 1969. Accumulation and translocation of sorbitol in apple phloem. Aust. J. Biol. Sci. 22:611-620.

Chaplin, P.J. and G.A. Catlin. 1976. Growth stages in fruit trees. New York Food Life Sci. Bul. No. 58.

Corelli Grappadelli, L., A.N. Lakso, and J.A. Flore. 1994. Early season patterns of carbohydrate partitioning in exposed and shaded apple branches. J. Amer. Soc. Hort. Sci. 119:596-603.

Hansen, P. and J. Grausland. 1973. ${ }^{14} \mathrm{C}$-Studies on apple trees. VIII. The seasonal variation and nature of reserves. Physiol. Plant. 28:2432.

Hansen, P. and J. Grausland. 1978. Levels of sorbitol in bleeding sap and in xylem sap in relation to leaf mass and assimilate demand in apple trees. Physiol. Plant. 42:129-133.

Iida, M., N.A. Bantog, K. Yamada, K. Shiratake, and S. Yamaki. 2004. Sorbitol and other sugar-induced expressions of NAD-dependent sorbitol dehydrogenase gene in japanese pear fruit. J. Amer. Soc. Hort. Sci. 129:870-875.

Ito, A., H. Hayama, and Y. Kashimura. 2005. Partial cloning and expression analysis of genes encoding NAD-dependent sorbitol dehydrogenase in pear bud during flower bud formation. Sci. Hort. 103:413-420.

Li, T.H. and S.H. Li. 2007. Leaf responses of micropropagated apple plants to water stress: Changes in endogenous hormones and their influence on carbohydrate metabolism. Agr. Sci. China 6:58-67.

Lo Bianco, R., M. Reiger, and S.J.S. Sung. 1999. Activities of sucrose and sorbitol metabolizing enzymes in vegetative sinks of peach and correlation with sink growth rate. J. Amer. Soc. Hort. Sci. 124: 381-388.

Loescher, W.H. 1987. Physiology and metabolism of sugar alcohols in higher plants. Physiol. Plant. 70:553-557.

Loescher, W.H., G.C. Marlow, and R.A. Kennedy. 1982. Sorbitol metabolism and sink-source interconversions in developing apple leaves. Plant Physiol. 70:335-339.

McQueen, J.C. and P.E.H. Minchin. 2005. Brief look at sorbitol in 1-year-old shoots of apple Malus domestica. N.Z. J. Crop Hort. Sci. 33:81-87.

McQueen, J., P.E.H. Minchin, and W.B. Silvester. 2004. Changes in non-structural carbohydrate concentration in 1-year old shoots of 'Braeburn' apple Malus domestica over 2 consecutive years. N.Z. J. Crop Hort. Sci. 32:319-323.

Negm, F.B. and W.H. Loescher. 1979. Detection and characterization of sorbitol dehydrogenase from apple callus tissue. Plant Physiol. 64:69-73.

Nosarzewski, M., A.M. Clements, A.B. Downie, and D.D. Archbold. 2004. Sorbitol dehydrogenase expression and activity during apple fruit set and early development. Physiol. Plant. 121:391 398.

Nosarzewski, M. and D.D. Archbold. 2007. Tissue-specific expression of SORBITOL DEHYDROGENASE in apple fruit during early development. J. Expt. Bot. 58:1863-1872.

Oliveira, C.M. and C.A. Priestley. 1988. Carbohydrate reserves in deciduous fruit trees. Hort. Rev. (Amer. Soc. Hort. Sci.) 10:403430.

Park, S.W., K.J. Song, M.Y. Kim, J.H. Hwang, Y.U. Shin, W.C. Kim, and W.H. Chung. 2002. Molecular cloning and characterization of four cDNAs encoding the isoforms of NAD-dependent sorbitol dehydrogenase from the Fuji apple. Plant Sci. 162:513-519.

Pratt, C. 1988. Apple flower and fruit: Morphology and anatomy. Hort. Rev. (Amer. Soc. Hort. Sci.) 10:273-308.

Teo, G., Y. Suzuki, S.L. Uratsu, B. Lampinen, N. Ormonde, W.K. Hu, T.M. DeJong, and A.M. Dandekar. 2006. Silencing leaf sorbitol synthesis alters long-distance partitioning and apple quality. Proc. Natl. Acad. Sci. USA 103:18842-18847.

Tworkoski, T. and S. Miller. 2007. Rootstock effect on growth of apple scions with different growth habits. Sci. Hort. 111:335-343. 
Wang, S.Y., G.L. Steffens, and M. Faust. 1986. Effect of paclobutrazol on accumulation of carbohydrates in apple wood. HortScience 21: 1419-1421.

Webb, K.L. and J.W.A. Burley. 1962. Sorbitol translocation in apple. Science 137:766.

Yamada, K., H. Mori, and S. Yamaki. 1999. Gene expression of NADdependent sorbitol dehydrogenase during fruit development of apple Malus pumila Mill. var. domestica Schneid. J. Jpn. Soc. Hort. Sci. 68:1099-1103.

Yamaguchi, H., Y. Kanayama, and S. Yamaki. 1994. Purification and properties of NAD-dependent sorbitol dehydrogenase from apple fruit. Plant and Cell Physiol. 35:887-892.

Yamaguchi, H., Y. Kanayama, J. Soejima, and S. Yamaki. 1996. Changes in the amounts of the NAD-dependent sorbitol dehydroge- nase and its involvement in the development of apple fruit. J. Amer. Soc. Hort. Sci. 121:848-852.

Yamaki, S. and K. Ishiwaka. 1986. Roles of four sorbitol related enzymes and invertase in the seasonal alteration of sugar metabolism in apple tissue. J. Amer. Soc. Hort. Sci. 111:134137.

Zhang, C., K. Tanabe, F. Tamura, A. Itai, and M. Yoshida. 2007. Roles of gibberellins in increasing sink demand in japanese pear fruit during rapid fruit growth. Plant Growth Regulat. 52:161172.

Zhou, R., L. Cheng, and A.M. Dandekar. 2006. Down-regulation of sorbitol dehydrogenase and up-regulation of sucrose synthase in shoot tips of the transgenic apple trees with decreased sorbitol synthesis. J. Expt. Bot. 57:3647-3657. 